\title{
SISTEM PAKAR UNTUK IDENTIFIKASI MASALAH PRINTER CANNON SERI IP DAN MP DENGAN METODE DEMPSTER-SHAFER
}

\author{
Ali Mahmudi ${ }^{1}$, Sonny Prasetio ${ }^{2}$, Rudi Eka Harnadi ${ }^{3}$ \\ Teknik Informatika, Institut Teknologi Nasional Malang \\ Email: amahmudi@ hotmail.com¹ ${ }^{1}$,rudiekah@gmail.com ${ }^{3}$
}

\begin{abstract}
Abstrak
Printer adalah salah satu dari sekian banyak perangkat keras yang dapat membantu mempermudah pekerjaan manusia. Printer berfungsi untuk mencetak suatu dokumen, gambar, grafik dan data lainnya dari komputer ke media kerats atau lainnya. Salah satu merk printer yang cukup populer adalah Canon. Akan tetapi printer canon juga tidak lepas dari masalah kerusakan, mulai dari hasil print yang bergaris atau tidak bagus, tidak mau mencetak atau macet, terdapat komponen hardware yang rusak, hingga printer mengalami mati total (Matot). Karena kekurangtahuan pengguna dalam menghadapi masalah atau kerusakan pada inkjet printer canon, sehingga pengguna tidak dapat secara cepat dan tepat menganalisa dan menemukan pemecahannya. Aplikasi ini untuk membantu pengguna dalam memecahkan masalah atau kerusakan pada inkjet printer canon.

Penelitian ini menggunakan Dampster-shafer sebagai metode yang mampu menyelesaikan permasalahan berdasarkan nilai kepercayaan. Penelitian ini menggunakan algoritma penelusuran Breadth-first search yang digunakan untuk melakukan pencarian atribut secara melebar. Metode penalaran maju / forward chaining digunakan sebagai pondasi utama dalam penelitian. Karena metode Dempster-shafer merupakan metode dari suatu teori matematika untuk pembuktian berdasarkan Belief functions and plausible reasoning (fungsi kepercayaan dan pemikiran yang masuk akal), yang digunakan untuk mengkombinasikan potongan informasi yang terpisah (bukti) untuk mengkalkulasi kemungkinan dari suatu peristiwa.
\end{abstract}

Kata Kunci : Sistem Pakar, Identifikasi Kerusakan inkjet printer, Dempster-shafer, Breadth-first search

\section{PENDAHULUAN}

\section{A. Latar Belakang}

Printer adalah suatu perangkat keras untuk mencetak dokumen, gambar, grafik atau data lainnya. Salah satu merk printer yang cukup popular adalah canon inkjet printer. Canon inkjet printer memiliki beberapa kelebihan, yakni harga relatif ekonomis, hasil cetak (gambar) cukup bagus, dan high speed. Akan tetapi, printer terkadang mengalami masalah atau kerusakan, seperti hasil print bergaris atau tidak bagus, gagal mencetak atau macet, terdapat komponen hardware yang rusak, hingga inkjet printer mengalami mati total.

Dikarenakan kekurangtahuan pengguna dalam mengidentifikasi masalah atau kerusakan pada inkjet printer, diperlukan seorang ahli / 'pakar' untuk memperbaiki printer.

\section{B. Rumusan Masalah}

Berdasarkan uraian latar belakang diatas, maka dapat dirumuskan suatu permasalahan yaitu bagaimana membuat aplikasi untuk mengidentifikasi kerusakan pada inkjet printer canon sekaligus dengan cara memperbaikinya dengan menggunakan metode Dempster-Shafer. Yang menjadi masalahnya adalah :

1. Bagaimana membangun aplikasi sistem pakar yang dapat mengidentifikasi masalah atau kerusakan pada inkjet printer canon seri IP dan MP ?

2. Bagaimana menginteraksikan sistem tersebut dalam sebuah basis data agar basis pengetahuan dari sistem tersebut dapat terus di update?

\section{Tujuan}

Tujuan dari penelitian ini adalah membuat aplikasi untuk mengetahui penyebab kerusakan inkjet printer canon beserta cara memperbaikinya.

\section{Batasan Masalah}

Batasan masalah dalam penelitian ini adalah

1. Inkjet printer canon yang dibahas kali ini haya 2 yaitu seri IP (IP1200, IP1300, IP1600, IP1700, IP1800, IP1980, IP2770, IP8770) dan seri MP (MP145, MP160, MP198, MP276, MP2370) .

2. Data pakar yang digunakan berasal dari penlitian atau survey yang di HI- 
COMTEC yang beralamat di Jl. MT Haryono 1A. Ruko Istana Dinoyo Blok. A3 Malang.

3. Pembangunan sistem pakar menggunakan metode Dempster-shafer.

4. Proses yang dilakukan adalah melakukan identifikasi masalah atau kerusakan pada inkjet printer canon terhadap gejala yang diinputkan oleh user, kemudian menampilkan hasil berupa nilai densitas, nama kerusakan dan pemecahanya.

\section{LANDASAN TEORI}

\section{A. Sistem Pakar}

Sistem pakar expert system adalah sistem yang berusaha mengapdosi pengetahuan manusia ke komputer, agar komputer dapat menyelesaikan masalah seperti yang biasa dilakukan oleh para ahli. Sistem pakar yang baik dirancang agar dapat menyelesaikan suatu permasalahan tertentu dengan meniru kerja dari para ahli. Dengan sistem pakar, orang awam pun dapat menyelesaikan masalah yang cukup rumit yang sebenarnya hanya dapat diselesaikan dengan bantuan para ahli. Bagi para ahli, sistem pakar juga akan membantu aktivitasnya sebagai asisten yang sangat berpengalaman. Sistem pakar adalah salah satu cabang dari AI yang membuat penggunaan secara luas knowledge yang khusus untuk penyelesaian masalah tingkat manusia yang pakar (Muhammad Dahria, 2011).

\section{B. Dapster-Shafer}

Ada berbagai macam penalaran dengan model yang lengkap dan sangat konsisten, tetapi pada kenyataannya banyak permasalahan yang tidak dapat terselesaikan secara lengkap dan konsisten. Ketidak konsistenan yang tersebut adalah akibat adanya penambahan fakta baru. Penalaran yang seperti itu disebut dengan penalaran non monotonis. Untuk mengatasi ketidakkonsistenan tersebut maka dapat menggunakan penalaran dengan teori Dempster-Shafer (Samuel Ongkowijoyo, 2013).

Teori perhitungan Dempster-Shafer pertama kali diusulkan oleh Arthur P. Dempster (1967) kemudian dikembangkan oleh Glenn Shafer (1976) dianggap sebagai generalisai dari teori probabilitas Baycsian. Yang merupakan suatu teori matematika untuk pembuktian berdasarkan Belief functions and plausible reasoning (fungsi kepercayaan dan pemikiran yang masuk akal), yang digunakan untuk mengkombinasikan potongan informasi yang terpisah (bukti) untuk mengkalkulasi kemungkinan dari suatu peristiwa.

\section{Printer Canon Inkjet}

Printer Canon Inkjet Seri IP dapat dikatakan sebagai inkjet printer dengan satu fungsi atau Single Function. Fungsi yang dimaksudkan yaitu hanya mampu mencetak atau print data. Printer seri IP yang dimaksud meliputi IP1200, IP1300, IP1600, IP1700, IP1800, IP1980, IP2770, dan IP8770.

Printer Canon Inkjet Seri MP dapat dikatakan sebagai inkjet printer dengan dua fungsi atau Multi-Function. Fungsi yang dimaksudkan yaitu hanya mampu melakukan scan-copy dengan atau tanpa batuan komputer dan mencetak atau print data melalui bantuan PC, laptop, dan prangkat pendukung lainya saat akan melakukan print. Printer seri MP yang dimaksud meliputi MP145, MP160, MP198, dan MP2370.

\section{PERANCANGAN}

\section{A. Kebutuhan Fungisonal}

Tabel 1 menunjukkan kebutuhan fungsional sistem yang akan dibangun.

Tabel 1 Kebutuhan Fungsional Sistem

\begin{tabular}{|c|c|c|}
\hline Akses & Kode & Keterangan \\
\hline \multirow{6}{*}{ Admin } & 101 & $\begin{array}{l}\text { Dapat masuk } \\
\text { (login) sebagai } \\
\text { administrator }\end{array}$ \\
\hline & 102 & $\begin{array}{l}\text { Dapat melakukan } \\
\text { manajemen data } \\
\text { pada halaman data } \\
\text { berita terbaru, data } \\
\text { spesifikasi printer, } \\
\text { data profil, data } \\
\text { kerusakan printer, } \\
\text { data galeri printer, } \\
\text { data gejala printer, } \\
\text { data aturan } \\
\text { identifikasi. } \\
(C R U D \text { sistem) }\end{array}$ \\
\hline & 103 & $\begin{array}{l}\text { Dapat } \\
\text { memperbaharui } \\
\text { profil admin }\end{array}$ \\
\hline & 104 & $\begin{array}{l}\text { Dapat melihat data } \\
\text { buku tamu user }\end{array}$ \\
\hline & 105 & $\begin{array}{l}\text { Dapat melihat } \\
\text { grafik chart } \\
\text { pengguna inkjet } \\
\text { printer canon }\end{array}$ \\
\hline & 105 & Dapat keluar \\
\hline
\end{tabular}




\begin{tabular}{|c|c|c|}
\hline & & (logout) dari sistem \\
\hline \multirow{4}{*}{$\begin{array}{l}\text { User } \\
\text { (pegguna) }\end{array}$} & 201 & $\begin{array}{l}\text { Dapat mengunjungi } \\
\text { halaman berita } \\
\text { terbaru, data } \\
\text { spesifikasi printer, } \\
\text { info kerusakan } \\
\text { printer, galeri, dan } \\
\text { identifikasi } \\
\text { kerusakan printer }\end{array}$ \\
\hline & 202 & $\begin{array}{l}\text { Dapat mengisikan } \\
\text { formulir isian } \\
\text { singkat pengguna } \\
\text { inkjet printer canon } \\
\text { seri IP dan MP }\end{array}$ \\
\hline & 203 & $\begin{array}{l}\text { Dapat mengisikan } \\
\text { formulir isian buku } \\
\text { tamu sebelum } \\
\text { melakukan } \\
\text { idetifikasi } \\
\text { kerusakan inkjet } \\
\text { printer }\end{array}$ \\
\hline & 204 & $\begin{array}{l}\text { Dapat melakukan } \\
\text { identifikasi } \\
\text { kerusakan inkjet } \\
\text { printer canon seri IP } \\
\text { maupun MP }\end{array}$ \\
\hline
\end{tabular}

\section{B. Kebutuhan Non Fungisonal}

Kebutuhan non fungisonal yang harus dipenuhi sebagai berikut :

1. Antar Muka Perangkat Lunak

a. Sofware penyimpanan database menggunakan Mysql

Tabel 3 Tabel Kerusakan Inkjet priter Canon Seri IP

\begin{tabular}{|c|l|}
\hline Kode & \multicolumn{1}{|c|}{ Nama_kerusakan } \\
\hline ERIP02 & $\begin{array}{l}\text { Tidak ada kertas dalam baki } \\
\text { printer / not paper. }\end{array}$ \\
\hline ERIP03 & $\begin{array}{l}\text { Terjadi kerusakan pada ASF } \\
\text { roller penarik (patah, } \\
\text { tersangkut oleh barang } \\
\text { asing) kertas. }\end{array}$ \\
\hline ERIP04 & $\begin{array}{l}\text { Tidak ada tinta di dalam } \\
\text { cartridge / tinta pada } \\
\text { cartridge full. }\end{array}$ \\
\hline ERIP05 & $\begin{array}{l}\text { Salah satu atau kedua } \\
\text { cartridge tidak terpasang / } \\
\text { tidak terdeteksi oleh printer. }\end{array}$ \\
\hline ERIP07 & $\begin{array}{l}\text { Cartridge kotor / hangus / } \\
\text { rusak. }\end{array}$ \\
\hline ERIP08 & $\begin{array}{l}\text { Terjadi absorber full / platen } \\
\text { waste ink absorber. }\end{array}$ \\
\hline
\end{tabular}

\begin{tabular}{|c|l|}
\hline ERIP14\&15 & $\begin{array}{l}\text { Cartridge black (kotor / } \\
\text { hangus / rusak). }\end{array}$ \\
\hline ERIP16 & Ink remaining is unknown. \\
\hline
\end{tabular}

Tabel 4 Tabel Kerusakan Inkjet priter Canon Seri MP

\begin{tabular}{|c|c|}
\hline Kode & Nama_kerusakan \\
\hline ERMP02 & $\begin{array}{l}\text { Tidak ada kertas dalam baki } \\
\text { printer / not paper }\end{array}$ \\
\hline ERMP03 & $\begin{array}{l}\text { Terjadi kerusakan pada ASF } \\
\text { roller penarik (patah, tersangkut } \\
\text { oleh benda asing) kertas. }\end{array}$ \\
\hline ERMP04 & $\begin{array}{l}\text { Tidak ada tinta di dalam } \\
\text { cartridge / tinta pada cartridge } \\
\text { full }\end{array}$ \\
\hline ERMP05 & $\begin{array}{l}\text { Salah satu atau kedua cartridge } \\
\text { tidak terpasang / tidak terdeteksi } \\
\text { oleh printer. }\end{array}$ \\
\hline ERMP08 & $\begin{array}{l}\text { Terjadi absorber full / platen } \\
\text { waste ink absorber. }\end{array}$ \\
\hline ERMP14 & $\begin{array}{l}\text { Terjadi ink cartridges whose } \\
\text { destinations are wrong. }\end{array}$ \\
\hline ERMP15 & $\begin{array}{l}\text { Ink cartridge tidak terpasang / } \\
\text { rusak. }\end{array}$ \\
\hline ERMP16 & Ink remaining is unknown. \\
\hline $\begin{array}{l}\text { ERMP } \\
16 \& 19\end{array}$ & $\begin{array}{l}\text { Masalah pada scan head } \\
\text { alignment sheet. }\end{array}$ \\
\hline ERMP22 & $\begin{array}{l}\text { Terjadi error pada satu atau } \\
\text { kedua cartridge. }\end{array}$ \\
\hline ERMP23 & Terjadi errror pada paper feed. \\
\hline ERMP24 & $\begin{array}{l}\text { Terjadi error pada purge unit / } \\
\text { bagian pompa cleaning head. }\end{array}$ \\
\hline ERMP25 & $\begin{array}{l}\text { Terjadi error pada ASF (cam) } \\
\text { sensor. }\end{array}$ \\
\hline ERMP26 & $\begin{array}{l}\text { Terjadi error pada internal } \\
\text { temperature rise. }\end{array}$ \\
\hline ERMP27 & $\begin{array}{l}\text { Terjadi absorber full / platen } \\
\text { waste ink absorber > reset } \\
\text { dengan toolsnya. }\end{array}$ \\
\hline ERMP28 & $\begin{array}{l}\text { Terjadi error pada Ink cartridge } \\
\text { temperature rise. }\end{array}$ \\
\hline ERMP29 & $\begin{array}{l}\text { Terjadi error pada bagian } \\
\text { EEPROM printer. }\end{array}$ \\
\hline ERMP33 & $\begin{array}{l}\text { Terjadi error pada paper feed } \\
\text { position. }\end{array}$ \\
\hline $\begin{array}{l}\text { ERMP } \\
3515\end{array}$ & $\begin{array}{l}\text { Pada USB Host VBUD } \\
\text { overcurrent error. }\end{array}$ \\
\hline
\end{tabular}




\begin{tabular}{|c|l|}
\hline $\begin{array}{c}\text { ERMP } \\
3717\end{array}$ & $\begin{array}{l}\text { Motor driver printer tidak } \\
\text { normal. }\end{array}$ \\
\hline $\begin{array}{c}\text { ERMP } \\
4020\end{array}$ & $\begin{array}{l}\text { Terjadi error pada hardware lain } \\
\text { (banyak sebab) pada printer. }\end{array}$ \\
\hline ERMP42 & $\begin{array}{l}\text { Terjadi error pada scanner pada } \\
\text { printer. }\end{array}$ \\
\hline
\end{tabular}

b. Software editor menggunakan Notpad++ v6.6.8

c. Software desain tampilan menggunakan Potoshop CS3

2. Antar Muka User / Pengguna

a. Tampilan dalam bentuk website aplikasi dengan resolusi minimal 800 X 600 dan maksimal 1366 X 768 .

b. Kyboard dan mouse sebagai alat bantu untuk mengoprasikan website.

\section{Kebutuhan Bahan Penelitian}

Pada tahap penelitian atau konseptualisasi, ditentukan aspek-aspek apa saja yang terkait dari bagian gejala-gejala yang biasa muncul pada setiap kerusakan yang menyerang inkjet printer canon seri IP dan MP dengan mencantumkan cara penangananya. Kebutuhan bahan penelitian tersebut meliputi data kerusakan dan data relasi gejala dan kerusakan.

Data kerusakan tersebut meliputi data kerusakan inkjet printer canon seri IP dan MP seperti pada tabel 3 dan 4 .

Untuk data relasi gejala dan kerusakan pada kerusakan inkjet printer canon seri IP. Daftar gejala disimbolkan dalam bentuk :

1. GAIP : kode gejala seri

IP : 02, 03, 04, dan seterusnya, ditunjukkan pada tabel 5.

2. GAMP MP

: kode gejala seri

Kode kerusakan : 02, 03, 04, dan seterusnya ditunjukkan pada tabel 6 .

Dari data relasi gejala dan kerusakan pada table 5 dan 6 , direpresentasikan pada tabel aturan. Representasi pengetahuan ini digunakan untuk menentukan proses pencarian atau menentukan kesimpulan. Berikut ini beberapa daftar kerusakan dan gejala untuk mengetahui kerusakan inkjet printer canon.
Tabel 5 Tabel Relasi Gejala Dan Kerusakan Inkjet priter Canon Seri IP

\begin{tabular}{|c|c|c|c|c|c|c|c|c|}
\hline \multirow{2}{*}{ GEJALA } & \multicolumn{7}{|c|}{ KERUSAKAN } \\
\hline & \multicolumn{7}{|c|}{ ERIP } \\
\hline KODE & 02 & 03 & 04 & 05 & 07 & 08 & $14 \& 15$ & 16 \\
\hline GAIP01 & $\checkmark$ & & & & & & & \\
\hline GAIP02 & $\checkmark$ & & & & & & & \\
\hline GAIP03 & $\checkmark$ & $\checkmark$ & & & & & & \\
\hline GAIP04 & $\checkmark$ & & $\checkmark$ & & $\checkmark$ & & $\checkmark$ & $\checkmark$ \\
\hline GAIP05 & & $\checkmark$ & & & & & & \\
\hline GAIP06 & & & $\checkmark$ & $\checkmark$ & & & & \\
\hline GAIP07 & & $\checkmark$ & $\checkmark$ & & & $\checkmark$ & & \\
\hline GAIP08 & & & $\checkmark$ & & $\checkmark$ & & $\checkmark$ & $\checkmark$ \\
\hline GAIP09 & & & & $\checkmark$ & & & & \\
\hline GAIP10 & & & & $\checkmark$ & & & & \\
\hline GAIP11 & & $\checkmark$ & & $\checkmark$ & $\checkmark$ & $\checkmark$ & $\checkmark$ & \\
\hline GAIP12 & & & & & $\checkmark$ & & & $\checkmark$ \\
\hline GAIP13 & & & & & & $\checkmark$ & & \\
\hline GAIP14 & & & & & & $\checkmark$ & & \\
\hline GAIP15 & & & & & & & $\checkmark$ & $\checkmark$ \\
\hline
\end{tabular}

1. Kerusakan Pada Inkjet Printer Canon Seri IP

a. Tidak ada kertas dalam baki printer / not paper.

- Terdapat suara keras pada saat proses print di bagian bawah baki kertas.

- Lupa memasukan kertas dibaki printer saat print.

- Kertas tidak dapat ditarik oleh printer $>$ ASF roller (penarik kertas).

- Printer ngebling, lampu indikator STOP / RESET nyala berkedip (orange)

b. Terjadi kerusakan pada ASF roller penarik (patah, tersangkut oleh barang asing) kertas.

- Kertas tidak dapat ditarik oleh printer $>$ ASF roller (penarik kertas).

- Pemakaian printer lebih dari 1 - 2 tahun' an.

- Sering menggunakan kertas berdiameter tebal pada saat print.

- Printer tidak dapat tidak dapat digunakan untuk print sama sekali.

c. Tidak ada tinta di dalam cartridge / tinta pada cartridge full.

- Setelah dilakukan pengisian ulang tinta kedalam catridge dengan menggunakan jarum suntik.

- Printer tidak dapat tidak dapat digunakan untuk print sama sekali. 
- Sering kali dilakukan cleaning cartridge black dan color via driver printer.

- Printer ngebling, lampu indikator STOP / RESET nyala berkedip (orange).

d. Salah satu atau kedua cartridge tidak terpasang / tidak terdeteksi oleh printer.

- Selama 2 minggu cartridge tidak pernah beraktifitas / digunakan untuk print.

- Melakukan proses print dalam jumlah banyak selama berjam-jam non-stop.

- Pemakaian printer lebih dari 1 - 2 tahun' an.

- Setelah dilakukan pengisian ulang tinta kedalam catridge dengan menggunakan jarum suntik.

\section{Kerusakan Pada Inkjet Printer Canon} Seri MP

a. Tidak ada kertas dalam baki printer / not paper.

- Terdapat suara keras pada saat proses print di bagian bawah baki kertas.

- Lupa memasukan kertas dibaki printer saat print.

- Kertas tidak dapat ditarik oleh printer $>$ ASF roller (penarik kertas).
- Printer ngebling, lampu indikator STOP / RESET nyala berkedip (orange).

b. Terjadi kerusakan pada ASF roller penarik (patah, tersangkut oleh barang asing) kertas.

- Kertas tidak dapat ditarik oleh printer $>$ ASF roller (penarik kertas).

- Printer ngebling, lampu indikator STOP / RESET nyala berkedip (orange).

- Sering menggunakan kertas berdiameter tebal pada saat print.

- Pemakaian printer lebih dari 1 - 2 tahun' an.

c. Tidak ada tinta di dalam cartridge / tinta pada cartridge full.

- Setelah dilakukan pengisian ulang tinta kedalam catridge dengan menggunakan jarum suntik.

- Printer ngebling, lampu indikator STOP / RESET nyala berkedip (orange).

- Sering kali dilakukan cleaning cartridge black dan color via driver printer.

- Tinta catridge dalam kondisi low ink / waste ink pad full. 
Tabel 6 Tabel Relasi Gejala Dan Kerusakan Inkjet priter Canon Seri MP

\begin{tabular}{|c|c|c|c|c|c|c|c|c|c|c|c|c|c|c|c|c|c|c|c|c|c|c|}
\hline \multirow{3}{*}{$\begin{array}{c}\text { GEJALA } \\
\text { KODE }\end{array}$} & \multicolumn{22}{|c|}{ KERUSAKAN } \\
\hline & \multicolumn{22}{|c|}{ ERMP } \\
\hline & 02 & 03 & 04 & 05 & 08 & 14 & 15 & 16 & $\begin{array}{c}168 \% \\
19\end{array}$ & 22 & 23 & 24 & 25 & 26 & 27 & 28 & 29 & 33 & 3515 & 3717 & 4020 & 42 \\
\hline GAMP01 & $\sqrt{ }$ & & & & & & & & & & & & & & & & & $\checkmark$ & & & & \\
\hline GAMP02 & $\sqrt{ }$ & & & & & & & & & & & & & & & & & & & & & \\
\hline GAMP03 & $\sqrt{ }$ & $\checkmark$ & & & & & & & & & $\checkmark$ & & & & & & & & & & & \\
\hline GAMP04 & & & & & & & & & & & & & & & & & & & & & $\sqrt{ }$ & \\
\hline GAMP05 & & $\checkmark$ & & & & & & & & & $\checkmark$ & & & & & & & $\sqrt{ }$ & & & & \\
\hline GAMP06 & $\sqrt{ }$ & $\checkmark$ & $\sqrt{ }$ & $\sqrt{ }$ & $\sqrt{ }$ & $\sqrt{ }$ & $\sqrt{ }$ & $\sqrt{ }$ & & $\sqrt{ }$ & $\sqrt{ }$ & $\sqrt{ }$ & & & & & & $\sqrt{ }$ & & & & \\
\hline GAMP07 & & & $\checkmark$ & & & $\sqrt{ }$ & $\sqrt{ }$ & $\sqrt{ }$ & & & & & & & & & & & & & & \\
\hline GAMP08 & & & $\checkmark$ & . & & $\sqrt{ }$ & & $\sqrt{ }$ & & & & $\sqrt{ }$ & & & & $\checkmark$ & & & & & & \\
\hline GAMP09 & & & & $\sqrt{ }$ & & & & & & & & & & & & & & & & & & \\
\hline GAMP10 & & & & $\sqrt{ }$ & & & & & & & & & & $\checkmark$ & & $\sqrt{ }$ & & & & & & \\
\hline GAMP10 & & & & $\checkmark$ & & & & & & & & & & $\checkmark$ & & $\sqrt{ }$ & & & & & & \\
\hline GAMP11 & & $\checkmark$ & & $\sqrt{ }$ & & & & & & & $\sqrt{ }$ & & & & & & & & & & & \\
\hline GAIP12 & & & & & $\sqrt{ }$ & $\sqrt{ }$ & $\checkmark$ & $\sqrt{ }$ & & & & & & $\checkmark$ & & . & & & & & & \\
\hline GAMP13 & & & & & $\sqrt{ }$ & & & & & & & & & & $\sqrt{ }$ & & & & & & & \\
\hline GAMP14 & & & & & & & $\sqrt{ }$ & & & & & & & & & & & & & & & \\
\hline GAMP15 & & & & & & & & & & & & & & $\checkmark$ & & $\checkmark$ & & & v & & & $\sqrt{ }$ \\
\hline GAMP16 & & & & & & & & & $\sqrt{ }$ & & & & & & & & & & & & & \\
\hline GAMP17 & & & & & & & & & $\sqrt{ }$ & & & & & & & & & & & & & \\
\hline GAMP18 & & & & & & & & & & & & & & & & & & & & & & $\sqrt{ }$ \\
\hline GAMP19 & & & & & & & & & $\sqrt{ }$ & & & & & & & & & & & $\sqrt{ }$ & & \\
\hline GAMP20 & & & & & & & & & & $\sqrt{ }$ & & & & & & & & & & & & \\
\hline GAMP21 & & & & & & & & & & $\checkmark$ & & & & & & & & & & & & \\
\hline GAMP 22 & & & & & & & & & & $\checkmark$ & & & & & & & & & & & & \\
\hline GAMP23 & & & & & & & & & & & & $\checkmark$ & $\sqrt{ }$ & & & & & & & & $\sqrt{ }$ & \\
\hline GAMP24 & & & & & & & & & & & & $\checkmark$ & & & $\sqrt{ }$ & & & & & & & \\
\hline GAMP 25 & & & & & & & & & & & & & $\sqrt{ }$ & & & & & & & & & \\
\hline GAMP26 & & & & & & & & & & & & & & & $\sqrt{ }$ & & & & & & & \\
\hline GAMP27 & & & & & & & & & & & & & & & $\sqrt{ }$ & & & & & & & \\
\hline GAMP28 & & & & & & & & & & & & & $\checkmark$ & & & & $\checkmark$ & & $\sqrt{ }$ & $\sqrt{ }$ & & \\
\hline GAMP29 & & & & & & & & & & & & & $\sqrt{ }$ & & & & $\checkmark$ & & $\sqrt{ }$ & & $\sqrt{ }$ & \\
\hline GAIP30 & & & & & & & & & & & & & & & & & $\checkmark$ & & & & $\sqrt{ }$ & \\
\hline GAMP31 & & & & & $\sqrt{ }$ & & & & & & & & & & & & & & & & & \\
\hline GAMP32 & & & & & & & & & & & & & & & & & & & & & & $\sqrt{ }$ \\
\hline GAMP33 & & & & & & & & & & & & & & & & & & & & & & $\sqrt{ }$ \\
\hline GAMP34 & & & & & & & & & $\checkmark$ & & & & & & & & & & & & & \\
\hline GAMP35 & & & $\checkmark$ & & & & & & & & & & & & & $\checkmark$ & & & & & & \\
\hline GAMP36 & & & & & & & & & & & & & & & & & & & $\sqrt{ }$ & & & \\
\hline GAMP37 & & & & & & & & & & & & & & & & & & & & $\sqrt{ }$ & & \\
\hline GAMP38 & & & & & & & & & & & & & & $\checkmark$ & & & & & & & & \\
\hline GAMP39 & & & & & & & & & & & & & & & & & & $\sqrt{ }$ & & & & \\
\hline GAMP40 & & & & & & & & & & & & & & & & & $\checkmark$ & & & $\sqrt{ }$ & & \\
\hline
\end{tabular}




\section{A. Block Diagram}

Block diagram menggabarkan rangkaian diagram kombinasi pendekatan MVC dengan metode Depster-shafer. Sistem tersebut terdiri dari 3 bagian yaitu input, proses, dan output. Seperti pada gambar 1 .

\section{B. Flowchart}

Didalam perancangan flowchart tersebut terdapat beberapa flowchart dalam pembuatan aplikasi yaitu sebagai berikut :

1. Flowchart cara kerja sistem (gambar 2).

Flowchart ini menggambarkan cara kerja sistem (halaman identifikasi kerusakan printer) berdasarkan metode Dempstershafer, algoritma penelusuran Breadthfirst search dan forward chain hingga diperoleh hasil berupa diagnosa kerusakan, tingkat nilai densitas, dan penangananya. Seperti pada gambar 2 .

2. Flowchart cara kerja perhitungan metode dempster-shafer (gambar 3).

Flowchart ini menggambarkan cara kerja metode dempster-shafer berdasarkan Inputan data gejala dan evidence. Input minimum yang diperlukan sistem adalah 2 data gejala. Didalam proses jika gejala kurang dari dua dan lebih dari empat ( $\mathrm{g}<=2$ dan $\mathrm{g}>=4)$ maka sistem akan melakukan pengulangan. Setelah densitas akhir ditemukan kemudian ditarik kesimpulan berupa data kerusakan dan penanganan.

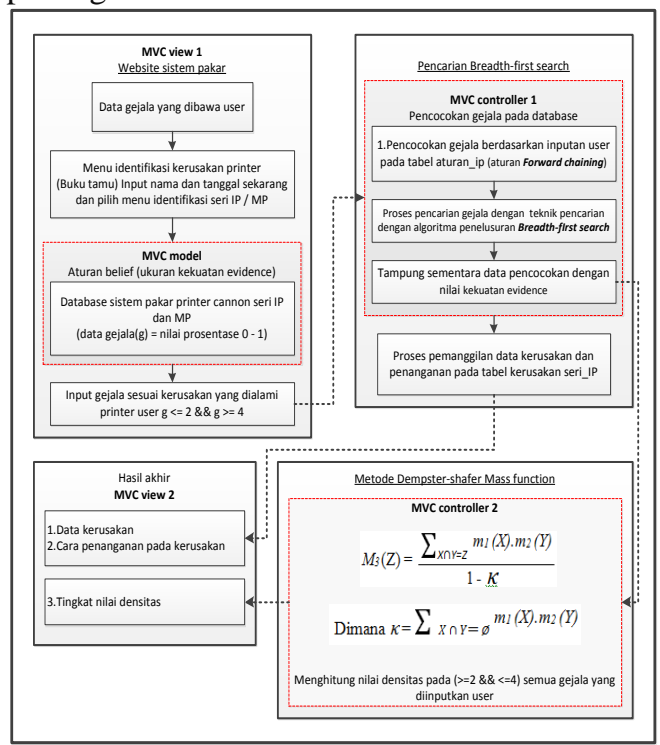

Gambar 1 Block Diagram Kombinasi MVC Dan Metode Dempster-Shafer

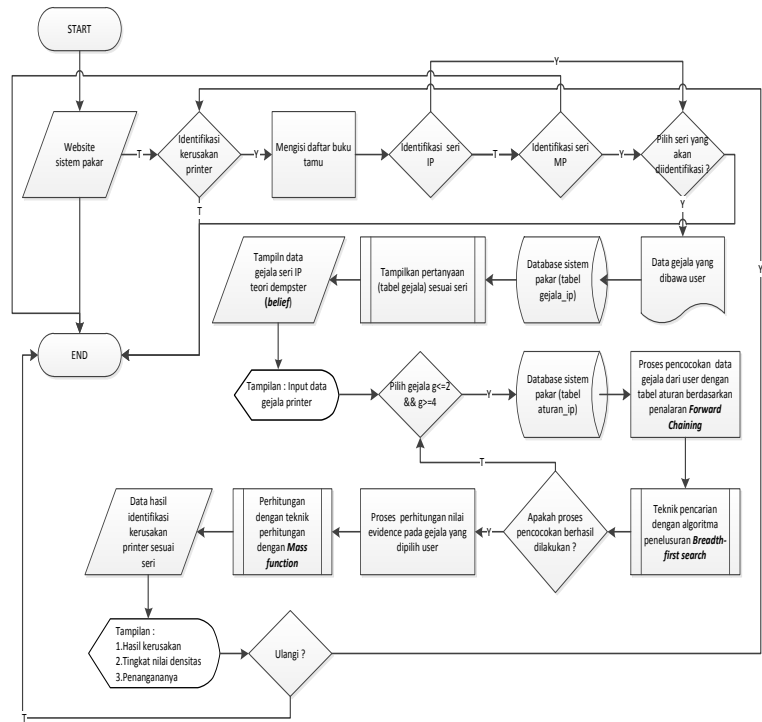

\section{Gambar 2 Flowchart Cara Kerja Sistem} Pada Website Sistem Pakar

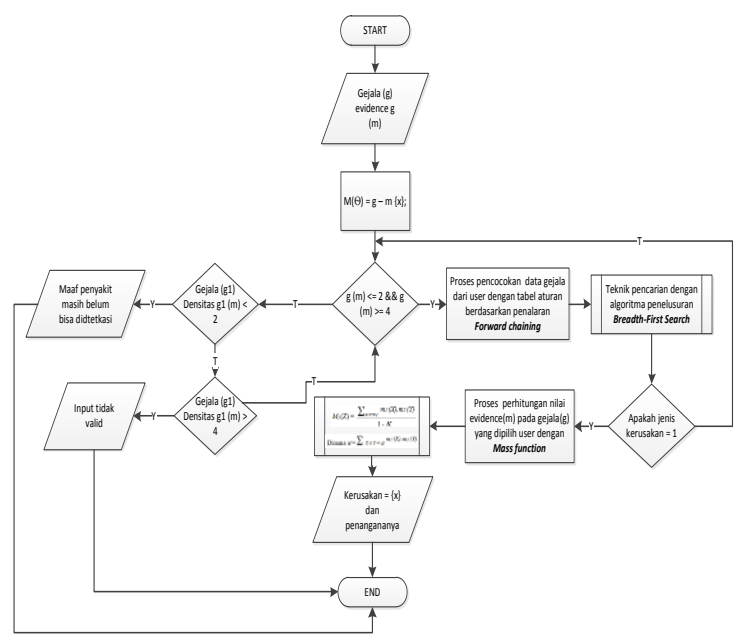

Gambar 3 Flowchart Cara Kerja Metode Dempster-Shafer

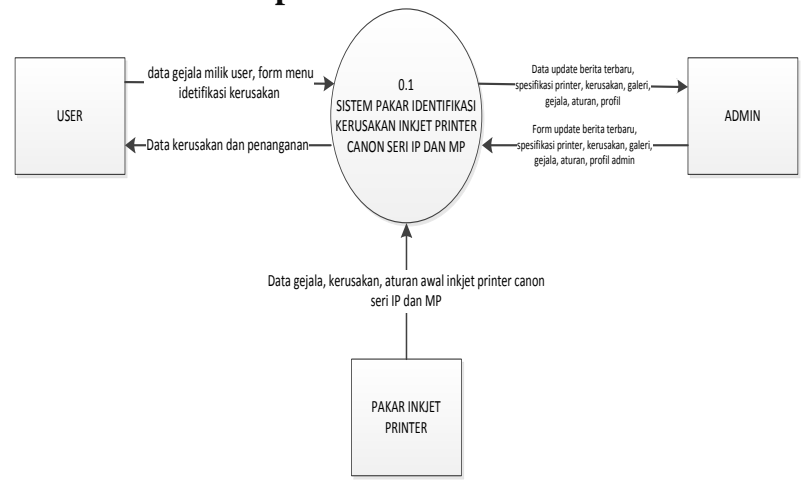

Gambar 4 Data Flow Diagram Level 0 Pada Aplikasi Sistem Pakar 


\section{Data Flow Diagram}

Didalam perancangan data flow diagram pada website terbagi menjadi dua level yakni level 0 dan level 1. Data flow diagram level 0 dan level 1 ditunjukkan pada gambar 4 dan 5 .

\section{Site Map}

1. Site map admin

Site map admin menjelaskan fitur-fitur yang dapat diakses oleh admin yang berjumlah delapan halaman, ditunjukkan pada gambar 6.

2. Site map pada user

Site map tersebut menjelaskan fitur-fitur yang dapat diakses oleh user yang berjumlah lima halaman, seperti ditunjukkan pada gambar 7 .

\section{Hasil}

Berikut ini beberapa tampilan halaman yang dapat diakses user, yaitu halaman berita terbaru (gambar 8) dan tampilan identifikasi kerusakan printer (gambar 9).

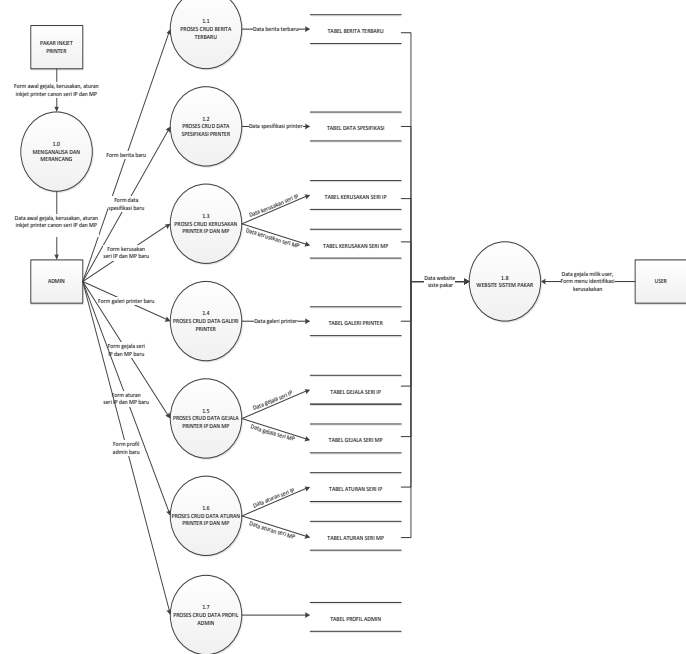

Gambar 5 Data Flow Diagram Level 1 Pada Aplikasi Sistem Pakar

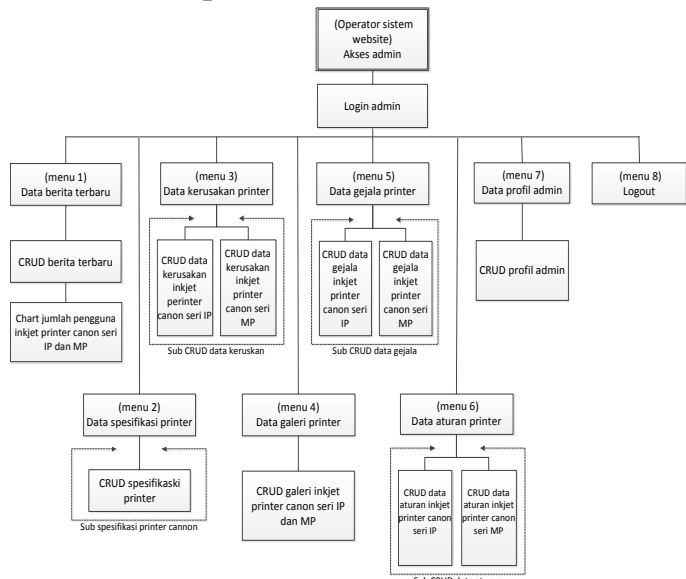

Gambar 6 Struktur Menu pada Aplikasi Pada Admin

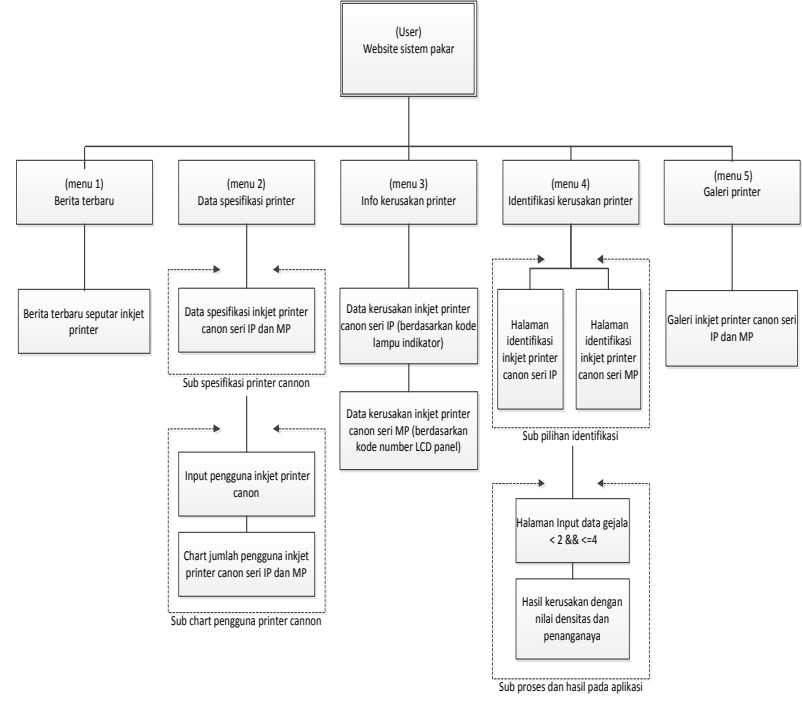

Gambar 7 Struktur Menu pada Aplikasi Pada User

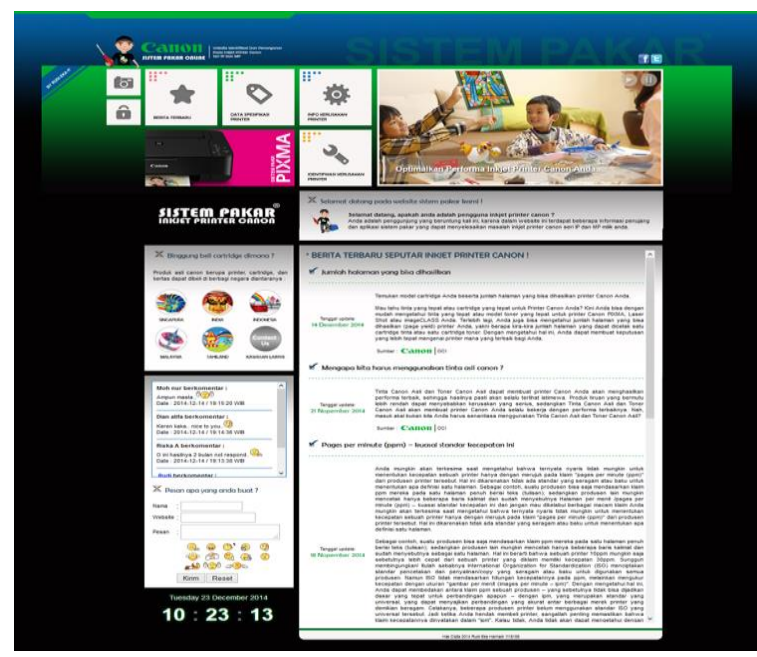

Gambar 8 TampilanHalaman Berita terbaru

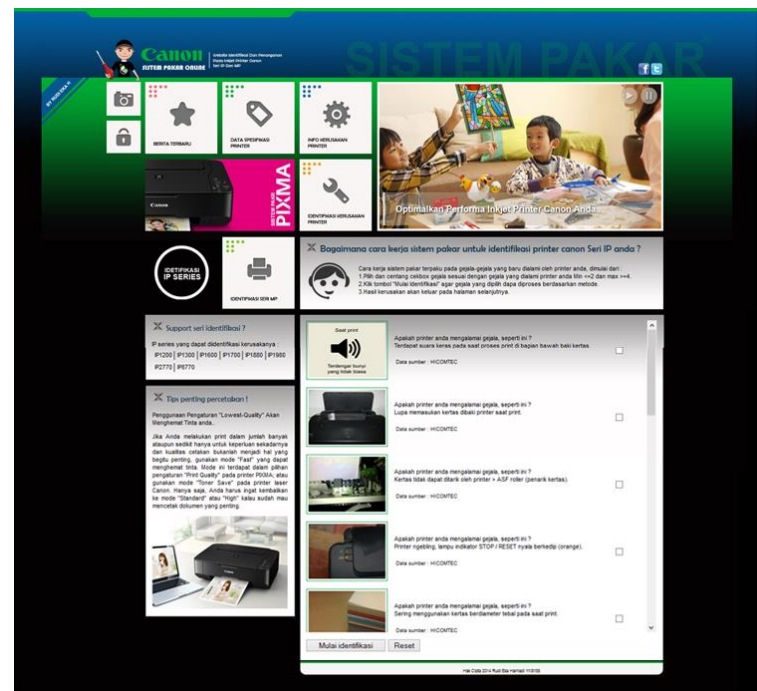

Gambar 9 Tampilan Halaman Identifikasi Kerusakan Printer Seri IP 
Sebagai contoh penulis memilih atau melakukan centang pada 3 gejala seperti pada gambar 10, yaitu :

1. Terdapat suara keras pada saat proses print di bagian bawah baki kertas.

2. Lupa memasukan kertas dibaki printer saat print.

3. Kertas tidak dapat ditarik oleh printer > ASF roller (penarik kertas).

proses selanjutnya adalah proses identifikasi kerusakan berdasarkan data gejala inputan dari yang dilakukan berdasarkan tombol (Mulai identifikasi), proses tersebut dilakukan berdasarkan berdasarkan metode Dempster-shafe. Hasil yang ditampilkan aplikasi ditunjukkan pada gamabr 11,

1. Nilai densitas kerusakan dalam bentuk persen dengan total nilai mencapai $99,6 \%$.

2. Kode error yang menunjukan error 02 (dalam bentuk gambar).

3. Keterangan kerusakan menunjukan Tidak ada kertas dalam baki printer / not paper.

4. Cara penanganannya meliputi yaitu masalah ini terjadi dikarenakan anda lupa / terlalu lama memasukan kertas.

a.masukan kertas kedalam baki printer, untuk berjaga-jaga isi kertas 25 lembar (anjuran dari perusahaan canon).

b.Tekan 1 kali tombol STOP / RESET, tunggu beberapa detik.

c. Maka printer anda akan mengulangi proses print yang gagal akibat tidak ada kertas tadi.

\section{Pengujian}

Pada tahap ini, pengujian dapar dilihat dari segi keakuratan serta kelayakan sistem pakar yang dibuat, maka dibutuhkan sebuah hasil kesimpulan dari 10 orang responden yaitu 9 orang kalangan umum dan 1 orang pakar. Penilaian berdasarkan kriteria sebagai berikut :
a. SS : Sangat sesuai
b. $\mathrm{S}$ : Sesuai
c. C : Cukup
d. $\mathrm{K}$ : Kurang

4. Pengujian pada user terhadap aplikasi sistem pakar ini didasarkan pada beberapa pertanyaan yang berhubungan dengan kerusakan ataupun masalah-masalah pada inkjet printer. Hasil pengujian ditunjukkan pada tabel 7 .

5. Kemudian, keakuratan hasil diagnosa aplikasi ini dibandingkan dengan hasil diagnosa pakar. Pengujian dilakukan terhadap 30 kerusakan inkjet printer. Dari 30 jenis masalah / kerusakan inkjet printer, 24 hasil identifikasi masalah dan penanganannya cocok dan sesuai dengan pemecahan masalah yang disampaikan oleh pakar / ahli. Sehingga, keakuratan aplikasi ini adalah $80 \%$.
6. Nilai keakuratan $=24.100 \%$
30
$=0.8 .100 \%$
$=\underline{\mathbf{8 0} \%}$

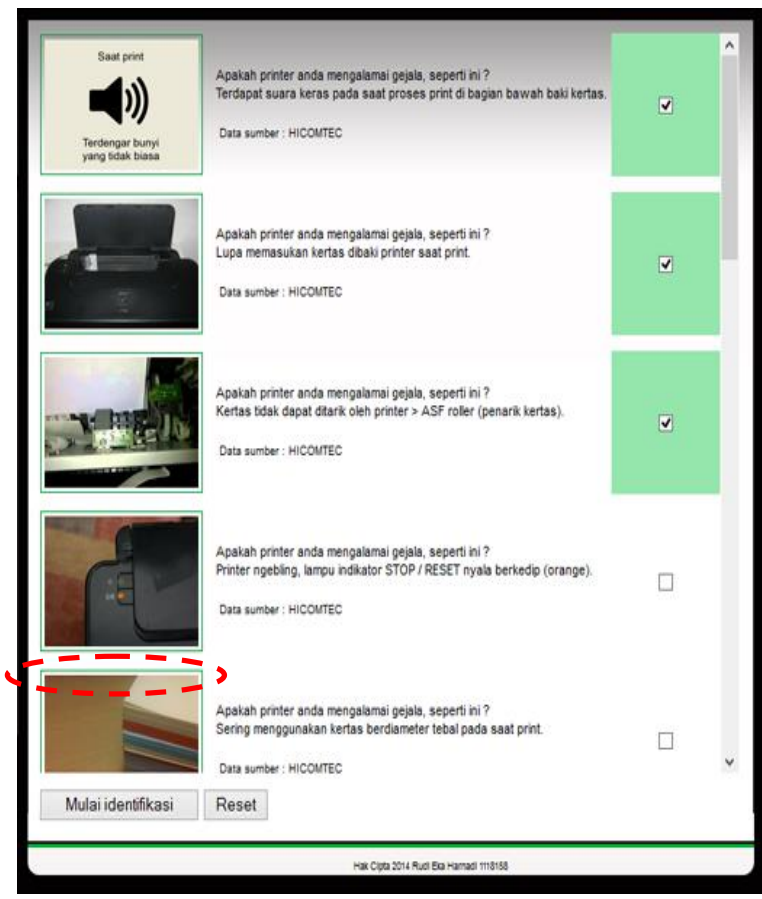

Gambar 10 Implementasi Proses Centang Gejala Pada Halaman Identifikasi

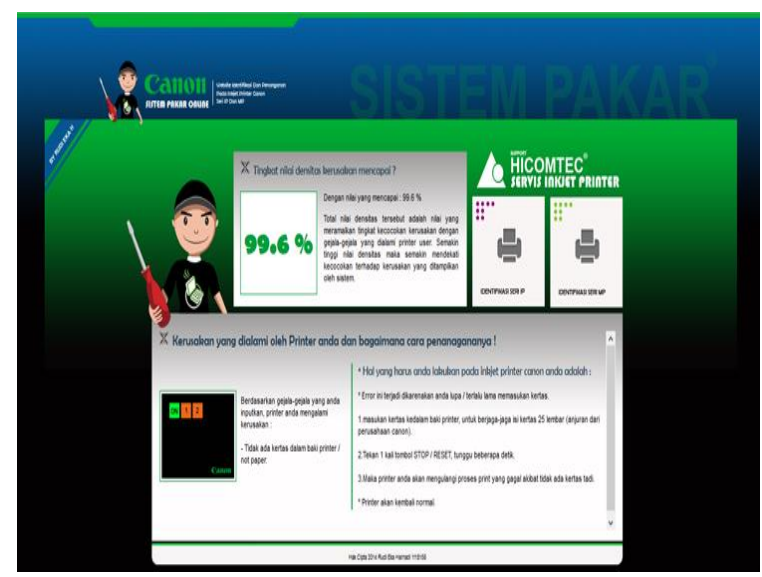

Gambar 11 Tampilan Halaman Hasil Identifikasi Kerusakan Printer Seri IP 
Tabel 7 Tabel Pengujian User Terhadap Sistem Pakar

\begin{tabular}{|c|c|c|c|c|c|}
\hline \multirow{2}{*}{ No } & \multirow{2}{*}{ URAIAN KRETERIA PENILAIAN } & \multicolumn{4}{|c|}{ REKAPITULASI PENILAIAN } \\
\cline { 3 - 6 } & SS & S & C & K \\
\hline 1 & $\begin{array}{l}\text { Tingkat kelengkapan materi informasi } \\
\text { kerusakan dan gejala pada sistem pakar }\end{array}$ & $70 \%$ & $30 \%$ & - & - \\
\hline 2 & $\begin{array}{l}\text { Tingkat akurasi hasil deteksi kerusakan } \\
\text { pada sistem pakar }\end{array}$ & $30 \%$ & $50 \%$ & $20 \%$ & - \\
\hline 3 & $\begin{array}{l}\text { Kesesuaian materi informasi kerusakan } \\
\text { dan gejala dengan kondisi nyata }\end{array}$ & $80 \%$ & $20 \%$ & - & - \\
\hline 4 & $\begin{array}{l}\text { Kelayakan sistem yang dibuat sebagai } \\
\text { pakar identifikasi kerusakan inkjet } \\
\text { printer }\end{array}$ & $50 \%$ & $50 \%$ & - & - \\
\hline
\end{tabular}

\section{Penutup}

A. Kesimpulan

Kesimpulan yang dapat diambil dari penelitian ini adalah

1. Hasil dari pengujian sistem adalah tingkat kelengkapan materi informasi kerusakan dan gejala pada sistem pakar mencapai $70 \%$ orang (kalangan umum) menyatakan sangat sesuai dan $30 \%$ orang (1 ahli inkjet printer dan 2 kalangan umum) menyatakan sesuai.

2. Hasil dari pengujian sistem adalah tingkat akurasi hasil deteksi kerusakan pada sistem pakar mencapai $30 \%$ orang (kalangan umum) menyatakan sangat sesuai, 50\% orang (1 ahli inkjet printer dan 4 kalangan umum) menyatakan sesuai, dan $20 \%$ orang (kalangan umum) menyatakan cukup.

3. Hasil dari pengujian sistem adalah kesesuaian materi informasi dan gejala dengan kondisi nyata mencapai $80 \%$ orang (kalangan umum) menyatakan sangat sesuai dan $20 \%$ orang (1 ahli inkjet printer dan 1 kalangan umum) menyatakan sesuai.

4. Berdasarkan hasil perbandingan pengujian antara hasil identifikasi pakar inkjet printer (ahli inkjet printer) dan sistem yang dibuat menghasikan nilai kelayakan $80 \%$ dan menyatakan bahwa sistem yang dibuat tersebut layak digunakan sebagai penganti pakar yang tidak ada ataupun berhalangan.

\section{B. Saran}

Didalam meningkatkan akurasi dan kelayakan pada sistem pakar yang dibuat, maka terdapat beberapa saran antara lain sebagai berikut :

1. Adanya penambahan kasus pada inkjet printer seri IP atau MP yang baru berupa (data kerusakan, gejala, dan aturan) seperti seri IP110, IP7270, dan IP2870 / IP2872.

2. Perlu ditambahkan fitur kosultasi antara user dengan pakar inkjet printer.

\section{Daftar Pustaka}

[1] Budiharto, Widodo. 2014. Web Programming Membangun Aplikasi Web Handal Dengan J2EE Dan MVC. Yogyakarta: C.V ANDI OFFSET (Penerbit ANDI).

[2] Dahria, $\quad 2011$. Pengembangan Sistem Pakar Dalam Membangun Aplikasi. Jurnal SAINTIKOM. 10, (3), 199-205.

[3] Gunawan, Hendra. 2014. Data Penelitian kerusakan Pada Inkjet Printer Canon Seri IP dan MP. Malang: HICOMTEC.

[4] Hakim, Lukman. 2010. Bikin Website Super Keren Denhan PHP \& jQuery. Yogyakarta: Lokomedia.

[5] Hakim, Lukman. 2014. Rahasia Inti MASTER PHP \& MySQLi(improved). Yogyakarta: Lokomedia.

[6] Kusumadewi, Sri. 2003. Artificial Intelligence Teknik dan Aplikasinya. Yogyakarta: Graha Ilmu.

[7] Ongkowijoyo, Samuel. 2013. Model penilaian keamanan situs web ecommerce Menggunakan kombinasi metode ahp, dempster-shafer Dan fuzzy topsis. Program Pascasarjana Universitas Diponegoro Semarang: Tidak Diterbitkan.

[8] Supriati, Endang. 2012. Troubleshooting PC Dengan Sistem Pakar. Program Pascasarjana Universitas Muria Kudus: Tidak Diterbitkan.

[9] Suyanto, 2014. Artificial Intelligence : Searching - Reasoning - Planing Learning (Edisi Revisi Kedua). Bandung: Penerbit INFORMATIKA.

[10] Wiswakarma, Komang. 2011. Teknik Cepat Menguasai CSS3. Yogyakarta: Lokomedia. 